\title{
Faktor-Faktor yang Mempengaruhi Pengungkapan Tanggung Jawab Sosial
}

\author{
Aditya Dharmawan Krisna ${ }^{1}$, Novrys Suhardianto ${ }^{*}$ \\ Fakultas Ekonomi dan Bisnis Universitas Airlangga, Jl. Airlangga 4, Surabaya 60286 \\ *Penulis korespondensi; E-mail: novrys@feb.unair.ac.id
}

\begin{abstract}
ABSTRAK
Penelitian ini bertujuan untuk menentukan faktor-faktor yang mempengaruhi luasnya tingkat pengungkapan tanggung jawab sosial perusahaan (Corporate Social Responsibility) dengan menguji pengaruh ukuran perusahaan, profitabilitas, leverage, kepemilikan institusional, ukuran dewan komisaris, ukuran dewan direksi, dan ukuran komite audit. Sampel yang digunakan adalah perusahaan sektor pertambangan terdaftar di Bursa Efek Indonesia selama 2010-2012. Data diperoleh dari laporan keuangan auditan dan laporan tahunan serta laporan keberlanjutan (sustainability report) jika ada. Penelitian ini menggunakan pendekatan kuantitatif dengan analisis regresi linear berganda. Penelitian ini menunjukkan bahwa ukuran perusahaan dan komite audit memiliki pengaruh positif terhadap pengungkapan tanggung jawab sosial. Tidak ditemukan bukti pengaruh profitabilitas, leverage, kepemilikan institusional, ukuran dewan komisaris, dan ukuran dewan direksi terhadap terhadap pengungkapan tanggung jawab sosial.
\end{abstract}

Kata kunci: Pengungkapan tanggung jawab sosial, ukuran perusahaan, profitabilitas, leverage, kepemilikan institusional, ukuran dewan komisaris, ukuran dewan direksi, ukuran komite audit.

\begin{abstract}
This research aims to determine the factors that influence the level of Corporate Social Responsibility Disclosures by testing the effect of corporate size, profitability, leverage, institutional ownership, board of director size, board of executive size, and audit committee size on corporate social responsibility disclosures index. Sample used are mining sector companies that listed on Indonesia Stock Exchange for period 2010-2012. The sources of the data were taken from audited financial reports and annual reports and sustainability report, if any. This research uses quantitative approach with multiple linier regression analysis. The results show that firms' size and audit committee size have a positive effect on corporate social responsibility disclosures. There is no evidence to suggest that profitability, leverage, institutional ownership, board of director size, and board of executive size have any effect on corporate social responsibility disclosures.
\end{abstract}

Keywords: Corporate Social Responsibility, company size, profitability, leverage, institutional ownership, board of director size, board of executive size, audit committee size.

\section{PENDAHULUAN}

Terdapat tiga tanggung jawab perusahaan yang harus dilakukan secara bersama-sama dan seimbang terhadap para pemegang kepentingan, yaitu tanggung jawab ekonomi, tanggung jawab atas hukum atau peraturan, dan tanggung jawab sosial (Post, 2002 dalam Hadi, 2014). Eklington (1997) menggunakan istilah "triple bottom-line profit, people, planet" (Hadi, 2014) untuk menjelaskan bahwa perusahaan tidak hanya memiliki tanggung jawab ekonomi kepada pemegang saham. Perusahaan juga memiliki tanggung jawab lingkungan dan sosial karena lingkungan dan masyarakat juga merupakan bagian dari para pemangku kepentingan.

Istilah tanggung jawab sosial perusahaan $($ Corporate Social Responsibility $=$ CSR $)$ muncul sebagai bentuk nyata dari pelaksanaan kewajiban perusahaan terhadap lingkungan sosial. Bowen (2013: 6) mendefinisikan CSR sebagai suatu kewajiban, untuk mengikuti kebijakan-kebijakan 
yang ada untuk membuat keputusan, atau untuk mengikuti tindakan yang diinginkan dalam arti objektif dan nilai yang ada di masyarakat (Moon dan Vogel, 2008:304). Menurut Guthrie dan Mathews (1985), tanggung jawab sosial perusahaan dapat diartikan sebagai ketersediaan informasi keuangan atau non-keuangan berkaitan dengan interaksi organisasi dengan lingkungan dan sosial, sebagaimana dinyatakan dalam laporan tahunan perusahaan atau laporan sosial terpisah (Hackston dan Milne, 1996; Sembiring, 2005). CSR tidak hanya tentang keberlangsungan hidup dan kelestarian alam, namun juga kesejahteraan para pekerja, masyarakat, dan komunitas secara luas, serta kenyamanan dan keamanan produk atau jasa.

Meningkatnya kesadaran masyarakat akan dampak kegiatan operasional perusahaan yang ditimbulkan secara tidak langsung mengubah sudut pandang perusahaan. Tanggung jawab sosial tidak lagi dipandang sebagai biaya yang menurunkan laba, namun sebagai investasi untuk dapat meningkatkan citra baik di mata masyarakat sehingga dapat meningkatkan laba jangka panjang serta mempertahankan legitimasi dan going concern perusahaan. Hal ini didukung oleh teori legitimasi yang menyatakan bahwa perusahaan harus mengambil tindakan yang dapat diterima secara sosial oleh masyarakat agar perusahaan dapat melanjutkan kegiatan operasionalnya (O'Donovan, 2002). Untuk memperoleh legitimasi, pemegang kepentingan harus mengetahui realisasi tanggung jawab sosial yang dilakukan perusahaan melalui pengungkapan CSR.

Pengungkapan tanggung jawab sosial perusahaan di Indonesia termasuk pengungkapan wajib (mandatory disclosure) karena telah ada regulasi yang mewajibkannya, salah satunya yaitu peraturan Bapepam nomor X.K.6 tentang penyampaian laporan tahunan emiten atau perusahaan publik yang berlaku sesuai dengan Keputusan Ketua Bapepam dan LK nomor Kep-431/BL/2012 tanggal 1 Agustus 2012. Akan tetapi peraturan tersebut hanya membagi aspek CSR ke dalam empat aspek besar, yaitu lingkungan hidup, ketenagakerjaan, masyarakat, dan tanggung jawab produk. Luas pengungkapan CSR dalam regulasi Bapepam tersebut hanya merupakan pengungkapan sukarela (voluntary disclosure). Walaupun legitimasi publik memaksa untuk melakukan pengungkapan secara rinci, tiap entitas bisnis memiliki pertimbangan tersendiri dalam menentukan luas pengungkapan tanggung jawab sosialnya. Penelitian ini bertujuan untuk menguji ada atau tidaknya pengaruh antara ukuran perusahaan, profitabilitas, leverage, kepemilikan institusional, dewan komisaris, dewan direksi, dan komite audit ter- hadap luas pengungkapan tanggung jawab sosial yang dilakukan oleh perusahaan sektor pertambangan yang terdaftar di Bursa Efek Indonesia.

\section{Karakteristik Perusahaan dan Pengungkap- an Tanggung Jawab Sosial}

Teori legitimasi menyatakan bahwa perusahaan berusaha mendapatkan pengakuan publik bahwa usaha yang telah dilakukan perusahaan adalah benar (Magness, 2006). Semakin besar sumber daya yang dimiliki perusahaan, maka semakin besar upaya perusahaan untuk memperoleh legitimasi dari seluruh pemangku kepentingan. Legitimasi dapat diperoleh dengan melaksanakan tanggung jawab sosial dan mengungkapnya dalam laporan tahunan (Rankin et al, 2011). Di samping itu, pelaksanaan tanggung jawab sosial juga dapat dijadikan sebagai media untuk menjaga reputasi perusahaan. Perusahaan besar memiliki political visibility yang tinggi sehingga tuntutan untuk lebih transparan ke publik semakin besar (Sembiring, 2003). Sejalan dengan bukti empiris Effendi dkk (2012) dan Prastiwi (2011), hipotesis berikut dirumuskan

$\mathrm{H}_{1}$ : Ukuran perusahaan berpengaruh positif terhadap luas pengungkapan CSR.

Hubungan antara kinerja perusahaan dan tingkat pengungkapan tanggung jawab sosial ditunjukkan dalam Freedman dan Jaggi (1988). Dengan menggunakan sampel industri penghasil polusi tinggi, Freedman dan Jaggi (1988) menunjukkan bahwa semakin tinggi laba perusahaan maka semakin tinggi luas pengungkapan tanggung jawab sosial. Perusahaan berusaha menunjukkan bukti bahwa laba yang diperoleh diikuti dengan aktivitas yang memulihkan kondisi lingkungan dengan pengurangan gas emisi. Di sisi lain, sudut pandang teori legitimasi menegaskan bahwa perusahaan seharusnya berupaya mendapat legitimasi dari pemangku kepentingan dengan mengungkapkan lebih banyak tentang dampak sosial lingkungan atas aktivitas perolehan labanya (Suryono dan Prastiwi, 2011).

$\mathrm{H}_{2}$ : Profitabilitas perusahaan berpengaruh positif terhadap luas pengungkapan CSR.

Teori keagenan menyebutkan bahwa pemegang saham sebagai prinsipal lebih berfokus pada pertumbuhan perusahaan jangka panjang dibandingkan dengan manajemen. Para pemegang saham lebih mengutamakan legitimasi publik untuk menjaga keberlangsungan hidup perusahaan dibandingkan dengan laba jangka pendek. Di sisi lain, fokus kreditor sejalan dengan pandangan 
pihak manajemen, yaitu laba jangka pendek untuk pengembalian piutangnya. Oleh sebab itu, Belkaoui \& Karpik (1989) menyatakan bahwa perusahaan dengan leverage tinggi memiliki kemampuan yang rendah dalam menjalankan kegiatan sosialnya dan berakibat rendahnya pengungkapan karena perusahaan berupaya tidak melanggar kontrak utang dengan mengurangi aktivitas pengurang laba. Sejalan dengan bukti empiris Effendi dkk (2012), penelitian ini mengajukan hipotesis berikut:

$\mathrm{H}_{3}$ : Leverage perusahaan berpengaruh negatif terhadap luas pengungkapan CSR.

Investor institusional dianggap lebih paham tentang pentingnya kontrak sosial dan legitimasi dari seluruh pemangku kepentingan serta menyadari adanya biaya keagenan yang mungkin muncul, sehingga membuat tanggung jawab sosial masuk ke dalam komponen pengawasan dan evaluasi. Teori stakeholder menjelaskan bahwa tiap pemangku kepentingan turut menentukan kinerja perusahaan, termasuk kinerja sosialnya. Institusi dianggap sebagai pihak yang paling mampu dalam mengawasi dan mengelola investasinya, baik dari segi pengetahuan, sistem informasi, maupun sumber daya yang dimiliki. 'Kepemilikan institusional yang tinggi akan menimbulkan usaha pengawasan yang lebih besar oleh pihak investor sehingga dapat menghalangi perilaku opportunistic manajer' (Machmud dan Djakman, 2008). Pernyataan tersebut didukung oleh Shleifer dan Vishny (1986) yang menyatakan bahwa investor institusional memiliki insentif untuk memantau pengambilan keputusan ketika porsi kepemilikannya besar.

Rawi dan Muchlish (2006) serta Machmud dan Djakman (2008) tidak menemukan adanya pengaruh kepemilikan institusional perusahaan terhadap luas pengungkapan CSR. Salah satu alasannya adalah ketidakjelasan status investor institusional dalam laporan tahunan yang mencakup investor jangka pendek seperti pialang saham atau perusahaan keuangan sejenis. Dengan demikian, penelitian ini tidak menghipotesiskan arah pengaruh kepemilikan institusional terhadap pengungkapan CSR.

$\mathrm{H}_{4}$ : Kepemilikan Institusional berpengaruh terhadap luas pengungkapan CSR.

Teori keagenan menyatakan adanya pembagian tugas antara pemilik saham dan manajemen. Dewan komisaris sebagai perwakilan para pemilik saham berperan sebagai pengawas kinerja perusahaan, termasuk kinerja sosial perusahaan. Hal ini dilakukan untuk memenuhi kepentingan seluruh pemangku kepentingan sebagaimana dinyatakan dalam teori stakeholder. Fungsi pengawasan lebih maksimal jika jumlah dewan komisaris memadai sehingga meningkatkan kinerja perusahaan. Sejalan dengan Sembiring (2005), penelitian ini berhipotesis bahwa

$\mathrm{H}_{5}$ : Ukuran dewan komisaris berpengaruh positif terhadap luas pengungkapan CSR.

Teori legitimasi menyatakan bahwa manajemen akan berusaha meraih legitimasi dari para pemangku kepentingan. Dewan direksi sebagai elemen tertinggi dari pihak manajemen bertanggung jawab atas perolehan legitimasi dari seluruh pemangku kepentingan. Ukuran dewan direksi mencerminkan mekanisme tata kelola perusahaan karena pengambilan keputusan direksi akan mempertimbangkan pendapat anggota direksi. Semakin besar ukuran dewan direksi, maka semakin besar kemampuan perusahaan untuk melaksanakan tanggung jawab sosial perusahaan (Ali dan Atan, 2013; Suryono dan Prastiwi, 2011; Pebriana, 2012).

$\mathrm{H}_{6}$ : Ukuran dewan direksi berpengaruh positif terhadap luas pengungkapan CSR.

Komite audit merupakan kepanjangan tangan dewan komisaris dalam hal pengawasan kinerja perusahaan, termasuk kinerja sosial. Pengawasan kinerja sosial dilakukan untuk mengakomodasi kepentingan seluruh stakeholder. Kinerja pengawasan tersebut juga akan semakin baik ketika jumlah anggota komite audit cukup untuk melakukan evaluasi terhadap seluruh aspek kinerja perusahaan. Semakin banyak anggota komite audit yang dimiliki, kontrol terhadap kinerja sosial perusahaan akan semakin besar sehingga memperluas pengungkapan tanggung jawab sosialnya (Suryono dan Prastiwi, 2011).

$\mathrm{H}_{7}$ : Ukuran komite audit berpengaruh positif terhadap luas pengungkapan CSR.

\section{METODE PENELITIAN}

Populasi dalam penelitian ini adalah seluruh perusahaan sektor pertambangan yang terdaftar di Bursa Efek Indonesia tahun 2010-2012. Sampel diambil dengan menggunakan metode purposive sampling sebagaimana ditunjukkan pada Tabel 1. Total sampel terpilih sebanyak 76 perusahaantahun. Nilai variabel penelitian ini bersumber dari laporan keuangan auditan dan laporan tahunan serta laporan tanggung jawab sosial jika disajikan secara terpisah yang diperoleh dari situs resmi Bursa Efek Indonesia. 
Tabel 1. Pemilihan sampel penelitian

\begin{tabular}{|c|c|c|c|c|}
\hline & \multirow[t]{2}{*}{ Kriteria/Batasan } & \multicolumn{3}{|c|}{$\begin{array}{l}\text { Jumlah perusahaan } \\
\text { periode t }\end{array}$} \\
\hline & & 2012 & 2011 & 2010 \\
\hline 1. & $\begin{array}{l}\text { Terdaftar di BEI per } 31 \\
\text { Desember periode } t\end{array}$ & 37 & 32 & 29 \\
\hline 2. & $\begin{array}{l}\text { Tidak terdaftar di BEI } \\
\text { per } 31 \text { Desember periode } \\
t+1\end{array}$ & 0 & 0 & (1) \\
\hline 3. & $\begin{array}{l}\text { Tidak mencantumkan } \\
\text { laporan keuangan } \\
\text { auditan dan laporan } \\
\text { tahunan per } 31 \\
\text { Desember periode t }\end{array}$ & (3) & (1) & (1) \\
\hline 4. & $\begin{array}{l}\text { Tidak mencantumkan } \\
\text { laporan keuangan } \\
\text { auditan dan laporan } \\
\text { tahunan per } 31 \\
\text { Desember periode t+1 }\end{array}$ & (3) & (3) & (1) \\
\hline 5. & $\begin{array}{l}\text { Keterbatasan informasi } \\
\text { dalam laporan keuangan } \\
\text { auditan dan laporan } \\
\text { tahunan yang } \\
\text { diterbitkan. }\end{array}$ & (2) & (3) & (4) \\
\hline & Jumlah sampel terpilih & 29 & 25 & 22 \\
\hline
\end{tabular}

Tabel 2. Definisi Operasional Variabel

\begin{tabular}{|c|c|c|}
\hline $\begin{array}{c}\text { Jenis } \\
\text { Variabel }\end{array}$ & Nama Variabel & Deskripsi Pengukuran \\
\hline Variabel & Kepemilikan & Jumlah saham \\
\hline \multirow[t]{11}{*}{ Independen } & Institusi (INS $\left.\mathrm{It}_{\mathrm{j}}\right)$ & $\begin{array}{l}\text { perusahaan yang dimiliki } \\
\text { institusi dibagi total } \\
\text { saham beredar } \\
\text { keseluruhan }\end{array}$ \\
\hline & Leverage & Total liabilitas perusahaan \\
\hline & $\begin{array}{l}\left({ }^{(D E R} \mathrm{j}_{\mathrm{jt}}\right) \\
\text { Profitabilitas }\end{array}$ & dibagi total ekuitas \\
\hline & $\left(\mathrm{ROA}_{\mathrm{jt}}\right)$ & $\begin{array}{l}\text { (earning after tax) } \\
\text { perusahaan dibagi total } \\
\text { aset perusahaan }\end{array}$ \\
\hline & Ukuran & Logaritma Natural \\
\hline & $\begin{array}{l}\text { Perusahaan } \\
\left.\text { (SIZE }{ }_{j t}\right)\end{array}$ & (Tot.Asset) \\
\hline & Ukuran Dewan & Jumlah dewan komisaris \\
\hline & $\begin{array}{l}\text { Komisaris } \\
\left(\mathrm{KOM}_{\mathrm{it}}\right)\end{array}$ & yang dimiliki perusahaan \\
\hline & Ukuran Dewan & Jumlah direksi yang \\
\hline & Direksi (DIR $\mathrm{Dit}_{\mathrm{t}}$ & dimiliki oleh perusahaan \\
\hline & $\begin{array}{l}\text { Ukuran komite } \\
\text { audit (AUD } \text { AUt })\end{array}$ & $\begin{array}{l}\text { jumlah komite audit yang } \\
\text { dimiliki perusahaan }\end{array}$ \\
\hline Variabel & Luas & Indeks pengungkapan \\
\hline \multirow[t]{2}{*}{ Dependen } & Pengungkapan & tanggung jawab sosial GRI \\
\hline & $\operatorname{CSR}\left(\operatorname{CSRDI}_{\mathrm{jt}+1}\right)$ & $\begin{array}{l}\text { G4 yang terdiri dari } 91 \\
\text { item dengan } \\
\text { menggunakan metode } \\
\text { content analysis (Global } \\
\text { Reporting Initiative, } \\
2013: 47-83) \\
\text { CSRDI }(t+1)=\sum \mathrm{X}_{\mathrm{ij}(\mathrm{t}+1)} / \mathrm{N}\end{array}$ \\
\hline
\end{tabular}

Definisi operasional variabel penelitian ini dipaparkan dalam Tabel 2. Variabel independen diperoleh dari pengamatan satu tahun sebelum variabel dependen. Analisis regresi linier berganda digunakan dalam menentukan pengaruh variabel independen dan satu variabel dependen (Ghozali dan Ratmono, 2013:57) dan kemudian digunakan dalam membangun persamaan untuk membuat prediksi (Kurniawan, 2011:36).

Model yang digunakan untuk menguji hipotesis penelitian ini adalah:

$$
\begin{aligned}
& \operatorname{CSRDI}_{j(t+1)}=\mathrm{a}+\mathrm{b} 1 \operatorname{SIZE}_{\mathrm{jt}}+\mathrm{b} 2 \mathrm{ROA}_{\mathrm{jt}}+\mathrm{b} 3 \mathrm{DER}_{\mathrm{jt}}+ \\
& \text { b4 INS } \mathrm{Ijt}_{\mathrm{j}}+\mathrm{b} 5 \mathrm{KOM}_{\mathrm{jt} t}+\mathrm{b} 6 \mathrm{DIR}_{\mathrm{jt}}+\mathrm{b} 7 \\
& \mathrm{AUD}_{\mathrm{jt}}+\mathrm{e}
\end{aligned}
$$

Uji asumsi klasik uji normalitas, uji multikolinieritas, uji heterokedastisitas dilakukan untuk memastikan bahwa model regresi dan masingmasing variabelnya layak untuk dilakukan pengujian hipotesis. Uji koefisien determinasi juga dilakukan untuk mengetahui besarnya pengaruh variabel-variabel independen terhadap variabel dependen.

\section{HASIL PENELITIAN DAN PEMBAHASAN}

\section{Analisis Statistik Deskriptif}

Statistik deskriptif (Tabel 3) menunjukkan bahwa tingkat pengungkapan tanggung jawab sosial yang dilakukan oleh rata-rata perusahaan pertambangan yang terdaftar di BEI masih tergolong rendah, yaitu sebesar $27,66 \%$ dari keseluruhan komponen GRI.

Penelitian ini menggunakan indikator pengungkapan CSR dari GRI G4. Dengan demikian, jumlah pengungkapan CSR yang diperoleh penelitian ini tidak bisa dibandingkan dengan penelitian lain yang menggunakan indikator berbeda. Dari 91 item pengungkapan CSR menurut GRI G4, rata-rata perusahaan tambang hanya mengungkapkan $27,66 \%$ atau berkisar 25 item. Variabel luas pengungkapan tanggung jawab sosial tidak 
terlalu bervariasi. Nilai rata-rata CSRDI lebih mendekati nilai minimumnya dibandingkan nilai maksimumnya. Meskipun nilai standar deviasi yang dimiliki cukup rendah, namun nilai CSRDI pada rata-rata sampel hanya berada di kisaran minimum.

Tabel 3. Statistik Deskriptif

\begin{tabular}{|c|c|c|c|c|}
\hline & $\begin{array}{l}\text { Rata- } \\
\text { rata }\end{array}$ & $\begin{array}{c}\text { Std. } \\
\text { Deviasi }\end{array}$ & $\begin{array}{l}\text { Mini- } \\
\text { mum }\end{array}$ & $\begin{array}{l}\text { Maksi- } \\
\text { mum }\end{array}$ \\
\hline $\begin{array}{l}\text { Ukuran Perusahaan } \\
\text { (SIZE) }\end{array}$ & 12.5827 & 0.73511 & 11.0479 & 13.8963 \\
\hline Profitabilitas (ROA) & 0.0794 & 0.12001 & -0.2226 & 0.4604 \\
\hline Lev & 2.1246 & 6.42703 & 0.1076 & 55.1643 \\
\hline $\begin{array}{l}\text { likan } \\
\text { ional (INS) }\end{array}$ & 0.6081 & 0.23279 & 0 & \\
\hline $\begin{array}{l}\text { Ukur } \\
\text { Komi }\end{array}$ & 4.88 & 1.826 & 2 & 10 \\
\hline Ukuran Dewan Direksi & 4.83 & 1.446 & 2 & 10 \\
\hline $\begin{array}{l}\text { Ukuran Komite Audit } \\
\text { (AUD) }\end{array}$ & 3.04 & 1.227 & 0 & \\
\hline $\begin{array}{l}\text { Pengungkapan CSR } \\
\text { (CSRDI) }\end{array}$ & 0.2766 & 0.16857 & 0.0549 & 0.8681 \\
\hline
\end{tabular}

Ukuran perusahaan sampel berada di kisaran 12 dan menunjukkan nilai yang merata diindikasikan oleh standar deviasi yang rendah dan kisaran antara nilai minimum dan maksimum tidak terlampau jauh. Hal ini akan sangat mendukung kemampuan analisis regresi dalam penelitian ini. Hasil analisis deskriptif menunjukkan bahwa variabel profitabilitas memiliki nilai minimal sebesar $-22,26 \%$ dan nilai maksimal sebesar $46,04 \%$ dengan standar deviasi yang cukup kecil yaitu 0,12001. Kendati dalam sampel terdapat perusahaan yang merugi, penelitian ini tidak mengeluarkannya karena keterbatasan jumlah perusahaan tambang yang go public. Nilai rerata DER yang cukup rendah dengan standar deviasi yang tinggi dan nilai maksimal 55\%. Variasi nilai DER yang tinggi diharapkan meningkatkan kemampuan tes meskipun nilai DER yang terlalu tinggi mengindikasikan kesulitan keuangan yang bisa mengancam hasil uji hipotesis.

Aspek tata kelola perusahaan diproksikan oleh kepemilikan institusional, ukuran dewan komisaris, dewan direksi, dan komite audit. Kepemilikan institusional rata-rata sampel sangat tinggi yaitu 60\% dengan standar deviasi yang rendah. Namun demikian, laporan tahunan tidak mengidentifikasi secara mendetail mengenai tujuan kepemilikan investor institusional. Rerata jumlah dewan komisaris dan direksi berada di kisaran 4 orang kendati perusahaan besar memiliki sampai 10 anggota komisaris dan direksi. Rerata komite audit adalah 3 orang dengan jumlah tertinggi 7 orang.

\section{Hasil Analisis Regresi Linier Berganda}

Secara umum, hasil uji asumsi klasik menunjukkan tidak ada persoalan serius. Model regresi dalam penelitian ini tidak mengalami gejala multikolinieritas karena nilai tolerance lebih dari 0,1 dan nilai VIF kurang dari 10 (tabel 4). Hasil uji glejser (tabel 4) menunjukkan bahwa seluruh variabel independen yang digunakan dalam penelitian ini tidak ada yang berpengaruh terhadap nilai residual menunjukkan tidak adanya gejala heterokedastisitas. Hasil uji normalitas terhadap faktor residual di persamaan (1) menunjukkan nilai Kolmogorov-Smirnov 1.522 yang tidak signifikan pada level $1 \%$. Selain itu, Large Sample Theory dalam Hayashi (2000: 89) menjelaskan bahwa estimasi regresi mendekati nilai rata-rata populasi ketika ukuran sampel cukup besar.

Koefisien determinasi (tabel 4) menunjukkan bahwa model yang digunakan pada penelitian ini hanya mampu menjelaskan variabilitas luas pengungkapan tanggung jawab sosial sebesar 38,1\%. Persentase selebihnya dijelaskan oleh variabel lain di luar penelitian.

Kendati koefisien yang diperoleh dari hasil analisis menunjukkan tanda sesuai hipotesis, sebagian besar variabel tidak menunjukkan pengaruh yang signifikan. Hanya dua variabel penelitian ini yang bisa menjelaskan variasi pengungkapan tanggung jawab sosial yaitu ukuran perusahaan dan ukuran komite audit.

\section{Ukuran Perusahaan dan Pengungkapan Tanggung Jawab Sosial}

Adanya pengaruh ukuran perusahaan terhadap luas pengungkapan CSR sejalan dengan penelitian yang dilakukan oleh Sembiring (2003), Magness (2006), Rankin et al (2011), Effendi dkk (2012), serta Suryono dan Prastiwi (2011). Teori legitimasi menyebutkan bahwa perusahaan berusaha mendapat pengakuan publik terkait bisnisnya. Semakin besar sumber daya yang dimiliki oleh perusahaan, semakin besar pula usaha yang dilakukan untuk memeroleh legitimasi tersebut melalui pelaksanaan dan pengungkapan tanggung jawab sosial perusahaan secara luas. Otorisasi dari manajer untuk melaksanakan kegiatan sosial juga terlihat lebih mudah diperoleh pada perusahaan besar (Belkaoui dan Karpik, 1989). Di samping itu, perusahaan besar memiliki political visibility yang lebih tinggi dan berusaha mengurangi dampak negatif pada lingkungan sosial (Hackston dan Milne, 1996) dengan melaksanakan dan mengungkapkan CSR. 
Tabel 4. Analisis regresi dan pengujian hipotesis.

\begin{tabular}{lcrrrrr}
\hline \multicolumn{1}{c}{ Variabel } & Hipotesis & Koefisien & \multicolumn{1}{c}{ t } & p-value & $\begin{array}{c}\text { VIF } \\
\text { (Tolerance) }\end{array}$ & $\begin{array}{c}\text { Signifikansi } \\
\text { Uji Glesjer }\end{array}$ \\
\hline Konstanta & &,- 899 & $-2,805$ &, $007^{* * *}$ & & $, 0,924$ \\
Ukuran Perusahaan (SIZE) & + &, 070 & 2,433 &, $018^{* *}$ & $1,894(0.5)$ & 0,917 \\
Profitabilitas (ROA) & + &, 147 & 1,081 &, 284 & $1,134(0.8)$ & 0,159 \\
Leverage (DER) & - &,- 002 &,- 923 &, 359 & $1,066(0.9)$ & 0,677 \\
Kepemilikan Institusional (INS) & $?$ &, 094 & 1,378 &, 173 & $1,065(0.3)$ & 0,473 \\
Ukuran Dewan Komisaris (KOM) & + &, 018 & 1,567 &, 122 & $1,814(0.6)$ & 0,280 \\
Ukuran Dewan Direksi (DIR) & + &, 001 &, 109 &, 913 & $1,183(0.8)$ & 0,563 \\
Ukuran Komite Audit (AUD) & + &, 046 & 3,552 &, $001^{* * *}$ & $1,095(0.9)$ & 0,235 \\
\hline
\end{tabular}

F: 7,584; Sign F: 0.000; Adj. R2 : 0,381

Variabel dependen: Pengungkapan CSR (CSRDI)

$* * *$ signifikan pada level 1\%, ${ }^{* *}$ signifikan pada level 5\%

\section{Profitabilitas dan Pengungkapan Tanggung Jawab Sosial}

Tidak adanya pengaruh signifikan profitabilitas terhadap luas pengungkapan CSR sejalan dengan penelitian yang dilakukan oleh Belkaoui dan Karpik (1989), Hackston dan Milne (1996), Sembiring (2003), Magness (2006), dan Effendi dkk (2012). Freedman dan Jaggi (1988) menyatakan bahwa perusahaan yang memiliki kinerja tinggi cenderung kurang memperhatikan pengungkapan tanggung jawab sosial karena perusahaan menjadi kurang sensitif terhadap reaksi negatif investor terhadap risiko lingkungan.

\section{Leverage dan Pengungkapan Tanggung Jawab Sosial}

Tidak adanya pengaruh leverage terhadap luas pengungkapan CSR sejalan dengan penelitian yang dilakukan oleh Rawi dan Muchlish (2006) serta Suryono dan Prastiwi (2011). Pandangan bahwa aktivitas CSR sebagai pengurang laba dan tuntutan institusional yang tidak cukup kuat membuat perusahaan di negara berkembang cenderung tidak menekankan CSR (Dobers dan Halme, 2009). Koefisien DER yang negatif menunjukkan bahwa semakin besar porsi kreditor dibanding para pemegang saham dalam perusahaan, manajer cenderung mengungkap tanggung jawab sosial perusahaan lebih sedikit untuk menghindari tekanan dari kreditor (Sembiring, 2003). Belkaoui dan Karpik (1989) berargumen bahwa perusahaan dengan leverage tinggi cenderung kurang bebas menggunakan sumber daya perusahaan untuk kegiatan sosial karena beresiko melanggar kontrak hutang.

\section{Kepemilikan Institusional dan Pengungkap- an Tanggung Jawab Sosial}

Tidak adanya pengaruh kepemilikan institusional terhadap luas pengungkapan CSR sejalan dengan penelitian yang dilakukan oleh Rawi dan Muchlish (2006) dan Machmud dan Djakman (2008. Walaupun dianggap sangat mampu dalam mengawasi dan mengelola investasinya, institusi sebagai pemilik dan salah satu pemangku kepentingan tidak memiliki pengaruh signifikan terhadap perusahaan dalam hal kinerja dan pengungkapan sosial. Investor institusional juga tidak terlihat berusaha untuk mengurangi biaya keagenan melalui tanggung jawab sosial. Namun demikian, penelitian ini menghadapi keterbatasan untuk memeroleh data kepemilikan institusional yang berperan dalam tata kelola perusahaan. Kepemilikan institusional yang diungkap dalam laporan tahunan tidak menjelaskan tentang tujuan kepemilikan. Kendati terdapat investor institusional, kinerja pengungkapan tanggung jawab sosial tidak berubah karena bisa jadi tujuan kepemilikan hanya untuk investasi jangka pendek.

\section{Dewan Komisaris dan Pengungkapan Tang- gung Jawab Sosial}

Tidak adanya pengaruh yang signifikan dewan komisaris terhadap luas pengungkapan CSR sejalan dengan penelitian yang dilakukan oleh Effendi dkk (2012). Intervensi yang diberikan oleh dewan komisaris pada pihak manajemen atas kinerja sosial perusahaan tidak terlalu tampak. Dewan komisaris lebih menerapkan fungsi pengawasannya pada kinerja keuangan perusahaan dibandingkan kinerja sosial (Effendi dkk, 2012).

\section{Dewan Direksi dan Pengungkapan Tang- gung Jawab Sosial}

Hasil uji hipotesis pada variabel ukuran dewan direksi sejalan dengan penelitian yang dilakukan oleh Haziwan (2013). Konflik keagenan tidak terlihat dalam lingkup tanggung jawab sosial. Jika dihubungkan dengan tidak berpeng- 
aruhnya variabel pemangku kepentingan lain terhadap luas pengungkapan tanggung jawab sosial, dewan direksi sebagai perwakilan pihak manajemen dengan otoritas tertinggi tampak melaksanakan apa yang menjadi harapan para pemangku kepentingan. Direksi lebih menginginkan kinerja keuangan yang baik dibandingkan memperoleh legitimasi publik melalui pelaksanaan tanggung jawab sosial.

\section{Komite Audit dan Pengungkapan Tanggung Jawab Sosial}

Adanya pengaruh antara komite audit terhadap luas pengungkapan CSR sejalan dengan penelitian yang dilakukan oleh Suryono \& Prastiwi (2011). Komite audit turut berperan dalam mengawasi dan memastikan agar pelaksanaan dan pengungkapan kegiatan sosial berjalan dengan baik (Collier, 1993 dalam Suryono \& Prastiwi, 2011). Komite audit sebagai kepanjangan tangan dewan komisaris juga memiliki fungsi yang sama dengan dewan komisaris yaitu fungsi pengawasan. Hal ini juga yang menyebabkan komite audit memberikan pengaruh yang lebih besar dibandingkan dewan komisaris terhadap luas pengungkapan tanggung jawab sosial. Perusahaan meningkatkan pengawasannya terhadap kegiatan sosial dengan meningkatkan jumlah komite audit. Semakin banyak jumlah komite audit, maka semakin baik fungsi pengawasan yang diberikan sehingga kegiatan sosial berjalan dengan lancar dan legitimasi dapat terjaga.

\section{Keterbatasan Penelitian}

Penelitian ini memiliki dua keterbatasan utama yang terletak pada karakteristik variabel dependen dan indikator penilai luas pengungkapan tanggung jawab sosial. Nilai rata-rata variabel CSRDI tergolong rendah, yaitu $27,66 \%$. Walaupun nilai standar deviasi cukup besar $(0,16857)$, variabel tersebut memiliki nilai rata-rata yang berada jauh di bawah nilai maksimumnya $(0,8681)$ dan mendekati nilai minimumnya $(0,0549)$. Rendahnya variabilitas variabel dependen dikhawatirkan mengurangi power of the test penelitian ini.

Penelitian ini menjadi tidak dapat dibandingkan dengan penelitian lain ketika masing-masing peneliti menggunakan indikator yang berbeda dalam menilai luas pengungkapan tanggung jawab sosial. Walapun indikator yang dikeluarkan oleh GRI dianggap paling tepat untuk digunakan pada penelitian ini, namun tidak menutup kemungkinan bahwa peneliti lain memiliki indikator berbeda yang dianggap lebih tepat. Pandangan yang berbeda terhadap penggunaan indikator yang tepat serta tidak adanya aturan pasti mengenai pengungkapan tanggung jawab sosial yang bersifat sukarela menyulitkan perbandingan hasil penelitian serupa.

\section{KESIMPULAN DAN SARAN}

Ukuran perusahaan dan komite audit terbukti memiliki pengaruh terhadap pengungkapan CSR. Hal ini menunjukkan bahwa visibilitas politik dan mekanisme tata kelola perusahaan berperan dalam menentukan luas pengungkapan CSR. Penelitian ini tidak berhasil membuktikan pengaruh profitabilitas, leverage, kepemilikan institusional, ukuran dewan komisaris, dan ukuran dewan direksi terhadap luas pengungkapan tanggung jawab sosial perusahaan.

Secara garis besar, penelitian ini tidak mampu mendukung teori stakeholder yang menyatakan bahwa setiap pemangku kepentingan mampu mempengaruhi perusahaan. Hal ini dikarenakan leverage, kepemilikan institusi, dewan direksi, dan dewan komisaris tidak berpengaruh terhadap luas pengungkapan tanggung jawab sosial. Penelitian ini juga tidak mampu membuktikan teori legitimasi dan kontrak sosial. Para pemangku kepentingan perusahaan bisa jadi tidak terlalu memperdulikan perolehan legitimasi dan kontrak sosial. Namun, tidak menutup kemungkinan bahwa pemangku kepentingan tetap memperhatikan legitimasi dan kontrak sosial. Dobers dan Halme (2009) menyatakan bahwa kekuatan institusi lingkungan negara berkembang, seperti Indonesia, berkontribusi pada rendahnya kegiatan dan pengungkapan CSR. Jamali dan Mirshak (2007) juga menegaskan bahwa kondisi institusional negara berkembang dalam menekankan kegiatan dan pengungkapan CSR mempengaruhi hasil penelitian pengungkapan CSR

Berdasarkan penelitian yang telah dilakukan, penelitian ini memiliki beberapa saran untuk penelitian selanjutnya. Berdasar hasil penelitian ini dan saran yang disampaikan oleh Dobers dan Halme (2009) maupun Jamali dan Mirshak (2007), penelitian ini menyarankan agar penelitian di masa mendatang memasukkan kekuatan institusi negara (regulasi) dalam pengaturan CSR. Namun demikian, regulasi CSR yang cukup ketat hanya ditemukan pada badan usaha milik negara (BUMN) namun tidak pada perusahaan pada umumnya. Lebih jauh, kesadaran masyarakat negara berkembang terhadap kondisi lingkungan bisa jadi mempengaruhi perilaku perusahaan dalam menjalankan dan mengungkapkan CSR. Membangun proksi kekuatan institusi dalam menekankan CSR merupakan tantangan riset di masa mendatang. 
Penelitian ini merekomendasi penelitian lanjutan yang berupaya membandingkan kemampuan setiap framework pengungkapan CSR. GRI memperbarui indikatornya secara rutin karena persepsi dan kebutuhan publik atas tanggung jawab sosial perusahaan selalu berubah dan bertambah. Namun demikian, penggunan GRI G4 sebagai indikator pengungkapan bukan kewajiban perusahaan yang akhirnya membuka peluang peneliti untuk menyusun indikator-indikator pengungkapan CSR yang beragam. Sebagai konsekuensinya, keragaman indikator pengungkapan CSR bisa mempengaruhi konsistensi hasil penelitian.

\section{DAFTAR PUSTAKA}

Ali, M.A. Mohd dan R. Atan. (2013). The Relationship Between Corporate Governance and Corporate Social Responsibility Disclosure: A Case of High Malaysian Sustainability Companies and Global Sustainability Companies. South East Asia Journal of Contemporary Business, Economics and Law, Vol. 3, Issue 1, 39-48.

Belkaoui, Ahmed dan Philip G. Karpik. (1989). Determinants of the Corporate Decision to Disclose Social Information. Accounting, Auditing and Accountability Journal, Vol. 2, No. 1, 36-51.

Bowen, Howard R. (2013). Social Responsibilities of the Businessman. Second Edition. Iowa City: University of Iowa Press.

Crowther, David dan Guler Aras. (2008). Culture and Corporate Social Responsibility. Leicester UK: Social Responsibility Network.

Dobers, Peter dan Minna Halme. (2009). Corporate Social Responsibility And Developing Countries. Corporate Social Responsibility Environment Management. Vol. 16, No. 5, 237-249

Effendi, Bahtiar, L. Uzliawati, dan A. S. Yulianto. (2012). Pengaruh Dewan Komisaris Terhadap Environmental Disclosure pada Perusahaan Manufaktur yang Listing di BEI Tahun 20082011. Simposium Nasional Akuntansi 15. Banjarmasin. 20-23 September 2012

Freedman, Martin dan Bikki Jaggi. (1988). An Analysis of The Association between Pollution Disclosure and Economic Performance. Accounting, Auditing and Accountability Journal, Vol. 1, No. 2, 43-58.

Ghozali, Imam dan Anis Chariri. (2007). Teori Akuntansi. Semarang: Badan Penerbit Universitas Diponegoro.

Ghozali, Imam dan Dwi Ratmono. (2013). Analisis Multivariat dan Ekonometrika. Semarang: Badan Penerbit Universitas Diponegoro.
Global Reporting Initiative. (2013). G4 Sustainability Reporting Guidelines: Reporting Principles and Standard Disclosures. Amsterdam: Global Reporting Initiative.

Guthrie, J.E. dan Mathews, M.R. (1985). Corporate social accounting in Australasia, Research in Corporate Social Performance and Policy. Vol. 7, 251-77.

Hackston, David dan Markus J. Milne. (1996). Some Determinants of Social and Environmental Disclosures in New Zealand Companies. Accounting, Auditing and Accountability Journal, Vol. 9, No. 1, 77-108.

Hadi, Nor. (2014). Corporate Social Responsibility. Yogyakarta: Graha Ilmu.

Handayani, Bestari Dwi. (2012). Corporate Social Responsibility dan Kinerja Perbankan di Indonesia. Jurnal Keuangan dan Perbankan, Vol. 16, No. 2, 318-328.

Hayashi, Fumio. (2000). Econometrics. United States of America: Princenton University Press.

Haziwan, Mohamad. (2013). The Relationship Between Corporate Social Responsibility Disclosure and Corporate Governance Characteristics in Malaysian Public Listed Companies. Social Science Research Network (Online), (http://papers.ssrn.com/sol3/papers. cfm?abstract_id=2276763, diakses 14 Februari 2015)

Jamali, Dima dan Ramez Mirshak. (2007). Corporate Social Responsibility (CSR): Theory and Practice in a Developing Country Context. Journal of Business Ethics. Vol 72, 243-262.

Kurniawan, Albert. (2011). SPSS: Serba-Serbi Analisis Statistika dengan Cepat dan Mudah. Yogyakarta: Jasakom.

Machmud, Novita dan Chaerul D. Djakman. (2008). Pengaruh Struktur Kepemilikan Terhadap Luas Pengungkapan Tanggung Jawab Sosial (CSR Disclosure) pada Laporan Tahunan Perusahaan: Studi Empiris pada Perusahaan Publik yang Tercatat di Bursa Efek Indonesia tahun 2006. Simposium Nasional Akuntansi 11. Pontianak. 23-26 Juli 2008

Magness, Vanessa. (2006). Strategic Posture, Financial Performance and Environmental Disclosure: An Empirical Test of Legitimacy Theory. Accounting, Auditing and Accountability Journal, Vol. 19, No. 4, 540-563.

Moon, Jeremy dan David Vogel. (2008). Corporate Social Responsibility, Government, and Civil Society. dalam buku Crane, Andrew, et al (Ed.). 2008. The Oxford Handbook of Corporate Social Responsibility. New York: Oxford University Press.

O’Donovan, Gary. (2002). Environmental Disclosures in the Annual Report: Extending The 
Applicability and Predictive Power of Legitimacy Theory. Accounting, Auditing and Accountability Journal, Vol. 15, No. 3, hlm. 344-371.

Pebriana, Umi Sukma. (2012). Pengaruh Profitabilitas, Leverage, Umur Perusahaan, Komposisi Dewan Direksi, dan Kepemilikan Institusional Pada Pengungkapan Corporate Social Responsibility (CSR) di Bursa Efek Indonesia. E-Jurnal Akuntansi Universitas Udayana, Vol. 1, No. 2. (Online), (http://ojs. unud.ac.id/index.php/Akuntansi/article/ view/2034, diakses 30 Desember 2014).

Rankin, Michaela, Carolyn Windsor, dan Dina Wahyuni. (2011). An Investigation of Voluntary Corporate Greenhouse Gas Emissions Reporting in A Market Governance System: Australian Evidence. Accounting, Auditing and Accountability Journal, Vol. 24, No. 8, 1037-1070.

Rawi dan Munawar Muchlish. (2010). Kepemilikan Manajemen, Kepemilikan Institusi, Leverage, dan Corporate Social Responsibility. Simposium Nasional Akuntansi 13. Purwokerto. 13-15 Oktober 2010.

Samuel, Hatane dan Elianto Wijaya. (2008). Corporate Social Responsibility, Purchase Intention dan Corporate Image pada Restoran di Surabaya dari Perspektif Pelanggan. Jurnal Manajemen Pemasaran, Vol. 3, No. 1, 35-54.
Sembiring, Eddy Rismanda. (2003). Kinerja Keuangan, Political Visibility, Ketergantungan pada Hutang, dan Pengungkapan Tanggung Jawab Sosial Perusahaan. Simposium Nasional Akuntansi 6, Surabaya. 16-17 Oktober 2003.

Sembiring, Eddy Rismanda. (2005). Karakteristik Perusahaan dan Pengungkapan Tanggung Jawab Sosial: Studi Empiris pada Perusahaan yang Tercatat di Bursa Efek Jakarta. Simposium Nasional Akuntansi 8. Solo. 15-16 September 2005.

Shleifer, Andrei and R.W. Vishny. (1986). Greenmail, White Knights, and Shareholders' Interest. The RAND Journal of Economics Vol. 17, No. 3, pp. 293-309

Suryono, Hari dan Andri Prastiwi. (2011). Pengaruh Karakteristik Perusahaan dan Corporate Governance Terhadap Praktik Pengungkapan Sustainability Report (SR): Studi pada Perusahaan-Perusahaan yang Listed (Go-Public) di Bursa Efek Indonesia (BEI) periode 2007-2009. Simposium Nasional Akuntansi 14. Aceh. 20-23 Juli 2011.

Yaparto, Marissa, et al. (2013). Pengaruh Corporate Social Responsibility Terhadap Kinerja Keuangan pada Sektor Manufaktur yang Terdaftar di Bursa Efek Indonesia pada Periode 2010-2011. CALYPTRA: Jurnal Ilmiah Mahasiswa Universitas Surabaya, Vol. 2, No.1. 1-19. 